\title{
Quantifying the impact of basin dynamics on the regional sea level rise in the Black Sea
}

\author{
Arseny A. Kubryakov ${ }^{1,2}$, Sergey V. Stanichny ${ }^{1}$, and Denis L. Volkov ${ }^{3,4}$ \\ ${ }^{1}$ Federal State Budget Scientific Institution “Marine Hydrophysical Institute of RAS”, Sevastopol, Russia \\ ${ }^{2}$ Institute of Earth Sciences, Saint Petersburg State University, St. Petersburg, Russia \\ ${ }^{3}$ Cooperative Institute for Marine and Atmospheric Studies, University of Miami, Miami, FL, USA \\ ${ }^{4}$ NOAA Atlantic Oceanographic and Meteorological Laboratory, Miami, FL, USA \\ Correspondence to: Kubryakov A. Arseny (arskubr@ya.ru)
}

Received: 29 August 2016 - Discussion started: 19 September 2016

Revised: 15 April 2017 - Accepted: 21 April 2017 - Published: 12 June 2017

\begin{abstract}
Satellite altimetry measurements show that the magnitude of the Black Sea sea level trends is spatially uneven. While the basin-mean sea level rise from 1993 to 2014 was about $3.15 \mathrm{~mm} \mathrm{yr}^{-1}$, the local rates of sea level rise varied from $1.5-2.5 \mathrm{~mm} \mathrm{yr}^{-1}$ in the central part to $3.5-$ $3.8 \mathrm{~mm} \mathrm{yr}^{-1}$ at the basin periphery and over the northwestern shelf and to $5 \mathrm{~mm} \mathrm{yr}^{-1}$ in the southeastern part of the sea. We show that the observed spatial differences in the dynamic sea level (anomaly relative to the basin-mean) are caused by changes in the large- and mesoscale dynamics of the Black Sea. First, a long-term intensification of the cyclonic wind curl over the Black Sea, observed in 1993-2014, strengthened divergence in the center of the basin and led to the rise of the sea level in coastal and shelf areas and a lowering in the basin's interior. Second, an extension of the Batumi anticyclone to the west resulted in $\sim 1.2 \mathrm{~mm} \mathrm{yr}^{-1}$ higher rates of sea level rise in the southeastern part of the sea. Further, we demonstrate that the large-scale dynamic sea level variability in the Black Sea can be successfully reconstructed using the wind curl obtained from an atmospheric reanalysis. This allows for the correction of historical tide gauge records for dynamic effects in order to derive more accurate estimates of the basin-mean sea level change in the past, prior to the satellite altimetry era.
\end{abstract}

\section{Introduction}

The mean sea level (MSL) rise in the Black Sea, as well as in the World Ocean, is mainly caused by the basin's freshwater budget and the thermal expansion of the water column due to warming (Stanev et al., 2000; Goryachkin and Ivanov, 2006; Jevrejeva et al., 2006; Cazenave and Llovel, 2010). The relative contribution of different components of the Black Sea sea level (BSSL) budget has been investigated in a number of earlier studies (e.g., Simonov and Altman, 1991; Stanev et al., 2000; Stanev and Peneva, 2001; Peneva et al., 2001; Tsimplis et al., 2004; Goryachkin and Ivanov, 2006; Grayek et al., 2009; Ilyin et al., 2012; Volkov and Landerer, 2015; Volkov et al., 2016; Aksoy, 2016). The estimates of the BSSL rise over the 20th century, based on tide gauge records, range from 1.5 to $2.5 \mathrm{~mm} \mathrm{yr}^{-1}$ (Boguslavsky et al., 1998; Reva, 1997; Tsimplis and Spencer, 1997; Goryachkin and Ivanov, 2006), which agrees with $\sim 1.8 \mathrm{~mm} \mathrm{yr}^{-1}$ of the global MSL rise during the 20th century (Church et al., 2004). Based on satellite altimetry measurements during 1993-2010, the global and the Black Sea MSL then rose at a faster rate of $3.1 \mathrm{~mm} \mathrm{yr}^{-1}$ (Church et al., 2013; Avsar et al., 2015). Both the tide gauge and altimetry records show that sea level trends in the Black Sea are not constant over time (e.g., Goryachkin and Ivanov, 2006; Kubryakov and Stanichnyi, 2013): MSL was rising at a very high rate of $\sim 28 \mathrm{~mm} \mathrm{yr}^{-1}$ in 1993 1999 (Ducet et al., 1999; Stanev et al., 2000; Cazenave et al., 2002; Goryachkin et al., 2003; Vigo et al., 2005; Yildiz et al., 2008), and then it began to fall by $\sim 3 \mathrm{~mm} \mathrm{yr}^{-1}$ in 1999-2007 (Ginzburg et al., 2011). 
The basin-wide satellite altimetry measurements have revealed that the BSSL change is not uniform, which is related to the dynamic factors that redistribute water within the basin (Stanev et al., 2000, 2001; Korotaev et al., 2001).The main feature of the Black Sea dynamics is the cyclonic Rim current flowing along the continental slope. The general cyclonic circulation results in a lower sea level in the interior of the basin and higher sea level along the coast (Blatov et al., 1984; Simonov and Altman, 1991; Oguz et al., 1993; Stanev, 1990; Stanev et al., 2000; Korotaev et al., 2001). It has been shown that the seasonal and interannual variability of the Black Sea circulation is driven by changes in the wind curl averaged over the basin (Blatov et al., 1984; Stanev, 1990; Stanev et al., 2000; Korotaev et al., 2001; Grayek et al., 2009; Kubryakov et al., 2016). In winter, the cyclonic wind curl and, therefore, the onshore Ekman transport increase and cause divergence in the center of the basin by moving water towards the coast. The compensating vertical uplift (Ekman suction) in the center of the sea brings cold and saline deep water to the surface, while warm and fresher surface water is pushed towards the coast, where downwelling motions occur (Stanev et al., 2000, 2004; Korotaev et al., 2001; Kubryakov et al., 2016). In summer, the cyclonic wind curl weakens, Ekman divergence decreases and the water accumulated along the coast flows back into the basin's interior (Zatsepin et al., 2002; Kubryakova and Korotaev, 2017).

Long-term changes of the Black Sea dynamics impact on the spatial heterogeneity of the sea level rise in the basin. Particularly, Vigo et al. (2005) and later Kubryakov and Stanichnyi (2013) showed that the Black Sea coastal sea level is rising 1.5-2 times faster than the sea level in the center of the basin. In this paper, we investigate the spatial structure of the BSSL trends, its relation to dynamic processes in the basin and atmospheric forcing. We also explore whether historic tide gauge measurements (prior to satellite altimetry era) can be corrected for dynamic effects in order to obtain better estimates of the basin-mean sea level change in the past.

The sea level rise leads to flooding of low-lying coastal areas and coastal erosion and, as a result, has a negative impact on human activities in the Black Sea coastal zone (Alpar, 2009; Avsar et al., 2016). Coastal erosion has been identified as one of the major problems for the Black Sea beaches (Demirkesen et al., 2007; Kos'Yan et al., 2012). Estimates show that rise of sea level by $1 \mathrm{~cm}$ results in 1-2 $\mathrm{m}$ of coastal erosion (Goryachkin and Ivanov, 2006). A rise of the sea level by $50 \mathrm{~cm}$ will reduce the area of the Black Sea beaches by approximately $50 \%$ (Allenbach et al., 2015). That is why the investigation into both the spatial variability of the sea level rise in the Black Sea and its causes is an important task for the coastal applications.

\section{Data and methods}

In this study, we used the regional satellite altimetry maps of sea level anomalies (SLAs) from January 1993 to December 2014, produced by Ssalto/Duacs and distributed by Aviso, with support from CNES (www.aviso.oceanobs. com). The maps are based on measurements by up to four satellites and produced on a daily basis with a horizontal grid spacing of $1 / 8^{\circ}$. The data are routinely corrected for instrumental errors and geophysical effects.

A dynamic atmospheric correction (DAC) is applied to account for the dynamic response of the sea level to atmospheric pressure and wind forcing (Carrère and Lyard, 2003). The DAC combines the high frequencies (periods $<20$ days) of a barotropic model of Lynch and Gray (1979) with the low frequencies (periods $>20$ days) of the inverted barometer correction, and it significantly reduces the aliasing of the high-frequency sea level variability, especially in coastal regions (Volkov et al., 2007). While it has been suggested that the IB correction may not be necessary in the almost enclosed Black Sea (Ginzburg et al., 2011), a recent study by Volkov et al. (2016) showed that on the interannual and longer timescales the BSSL responds to changes in atmospheric pressure in an inverted barometer manner, i.e., $1 \mathrm{mbar}$ change of pressure corresponds to an approximately $1 \mathrm{~cm}$ change in sea level.

Over the recent years, great progress in improving the near-coast measurements has been achieved, which has benefited the regional altimetry products, such as the Mediterranean and Black Sea products. The improvement in the coastal areas of the Mediterranean Sea has recently been demonstrated by Marcos et al. (2015). A reasonable agreement between tide gauge records and near-coast SLAs in the Black Sea has also been documented (Volkov and Landerer, 2015; Korotaev et al., 1998; Stanev et al., 2000, 2001; Goryachkin et al., 2003; Kubryakov et al., 2013; Avsar et al., 2015).

The absolute dynamic topography (ADT) of the Black Sea was computed as the sum of the mapped SLAs and a "synthetic" mean dynamic topography of Kubryakov and Stanichny (2011). The zonal and meridional components of the surface geostrophic velocities $\left(u_{g}, v_{g}\right)$ were computed from the absolute dynamic topography using geostrophic equations:

$u_{g}=-\frac{g}{f} \frac{\partial h}{\partial y} ; v_{g}=\frac{g}{f} \frac{\partial h}{\partial x}$,

where $h$ is the absolute dynamic topography, $f$ is the Coriolis parameter, and $g$ is the gravitational acceleration. To describe the basin-scale variability, we use the magnitude of geostrophic velocity $U=\sqrt{u_{g}^{2}+v_{g}^{2}}$. Altimetry-derived geostrophic velocities based on the comparison with drifters and hydrological data were validated in Kubryakov and Stanichny (2013) and Kubryakov et al. (2016). 

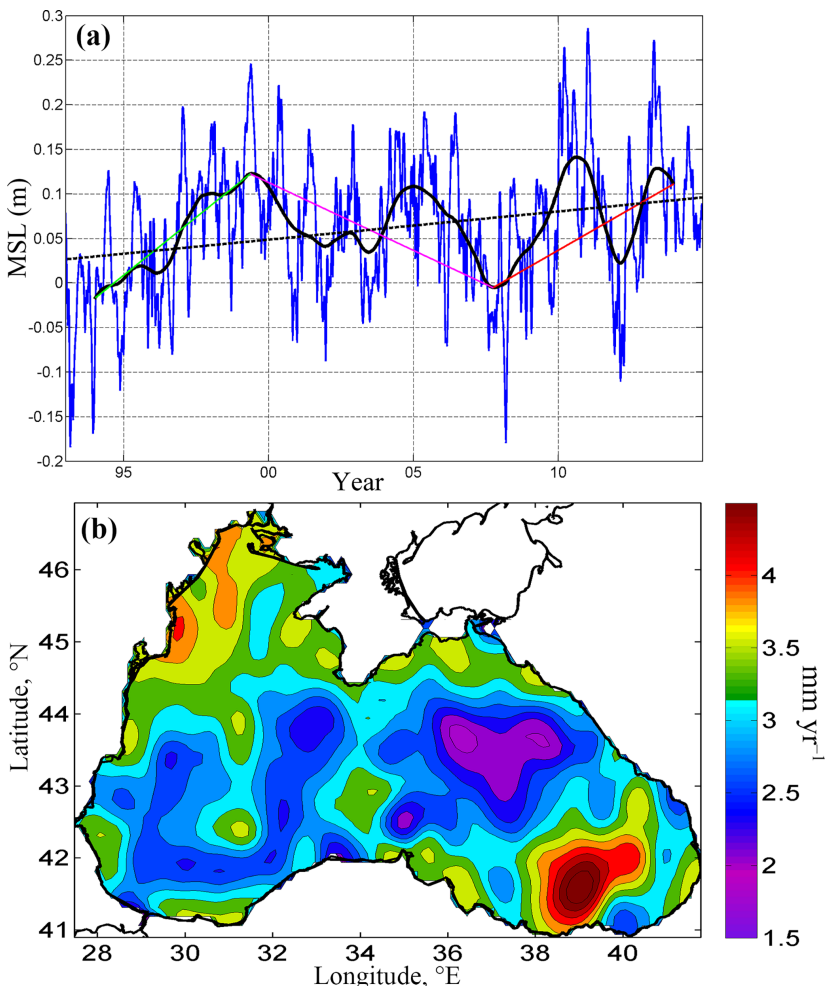

Figure 1. (a) Daily time series (blue curve) of the basin-averaged sea level of the Black Sea from satellite altimetry data. Black dotted line shows the linear trend; (b) spatial distribution of the 1993-2014 sea level trends $\left(\mathrm{mm} \mathrm{yr}^{-1}\right)$.

The variability of the BSSL is decomposed in two parts (e.g., Stanev et al., 2000; Grayek et al., 2009): (i) the basinaveraged sea level change related to the time-variable amount of water contained in the basin and steric effects and (ii) the dynamic sea level (DSL) change due to the redistribution of water within the basin. Because the response of SLAs to the low-frequency variability of the Black Sea water budget is almost spatially uniform (Korotaev et al., 2001), the DSL at a particular location $(x, y)$ is defined as the difference between the local $\operatorname{ADT}(x, y)$ and the basin-mean sea level, MSL: $\operatorname{DSL}(x, y)=\operatorname{ADT}(x, y)-\operatorname{MSL}$.

In addition to satellite altimetry data, we used the 6-hourly ERA-Interim winds at $10 \mathrm{~m}$ height (Dee et al., 2011) to compute the wind curl over the Black Sea in 1979-2014. It has been shown that the ERA-Interim winds over the Black Sea coincide well with in situ meteorological measurements, and describe the variability of the wind direction better than other reanalyses (e.g., MERRA, NCEP, and WRF) (Garmashov et al., 2016).

To study the variability of eddy dynamics in the Black Sea, we used an automated "winding angle" (Chaigneau et al., 2008) eddy identification method, described in detail in Kubryakov and Stanichny (2015a, b). For each eddy, the method defines its radius and maximum orbital velocity. At each grid point, it also defines the frequency of eddy observation, i.e., the fraction of the total time when the grid point is located within an eddy. Because the Black Sea anticyclones are larger and more powerful than cyclones (Oguz et al., 1993; Kubryakov and Stanichny, 2015a), in this study we only consider the properties of anticyclones.

\section{Results}

\subsection{Interannual variability of the BSSL}

The variability of the Black Sea MSL is shown in Fig. 1a. In 1993-2014, MSL was rising at a rate of $3.15 \pm 0.13 \mathrm{~mm}$ (black dotted line) per year, in agreement with Avsar et al. (2015). This value coincides well with the global MSL rise in 1992-2008 (e.g., Cazenave and Llovel, 2010). The trend has not been constant: sea level was rising in 19931999; then it was falling in 2000-2007, and in 2007-2014 it rose again (Fig. 1a). Similar sea level changes during the first two periods have already been reported by Vigo et al. (2005) and Yildiz et al. (2008), based on the analysis of satellite altimetry and gravimetry data. Changes in the amount of water in the Black Sea (water balance) are the main reason for the basin-averaged sea level variability (Stanev et al., 2000, 2002; Peneva et al., 2001; Ilyin et al., 2012; Volkov and Landerer, 2015; Volkov et al., 2016). An extensive review of the BSSL variability and water balance in the 20th century is provided in Goryachkin and Ivanov (2006).

The spatial distribution of sea level trends in the Black Sea over the 1993-2014 time period (Fig. 1c) shows that the sea level change is spatially non-uniform, in agreement with earlier analyses of the along-track altimetry data (Vigo et al., 2005; Kubryakov and Stanichniy, 2013). Sea level in coastal and shelf areas was rising at rates $3.2-4 \pm 0.2 \mathrm{~mm} \mathrm{yr}^{-1}$, which is approximately $1.5-2$ times greater than in the center of the basin $\left(1.5-2.5 \pm 0.25 \mathrm{~mm} \mathrm{yr}^{-1}\right)$. The largest trend, exceeding $5.0 \pm 0.25 \mathrm{~mm} \mathrm{yr}^{-1}$, is observed in the southeastern part of the basin. The observed spatial differences in the sea level rise are related to the basin dynamics, which redistributes water mass within the basin. Investigation into the reasons for this spatial variability is the main goal of the present study.

\subsection{Wind-driven dynamic sea level variability}

The main feature of the Black Sea dynamics is the cyclonic Rim current encircling the basin over the continental slope. The predominantly cyclonic wind curl over the basin causes the near-surface divergence in the basin's interior and downwelling motions and associated deepening of the pycnocline near the continental slope. This process generates horizontal density gradients that drive the along-slope baroclinic flow (Stanev, 1990; Stanev et al., 2000; Korotaev et al., 2001).

The seasonal variability of the Black Sea DSL is driven by the seasonal changes of the wind curl (Stanev et al., 2000; 

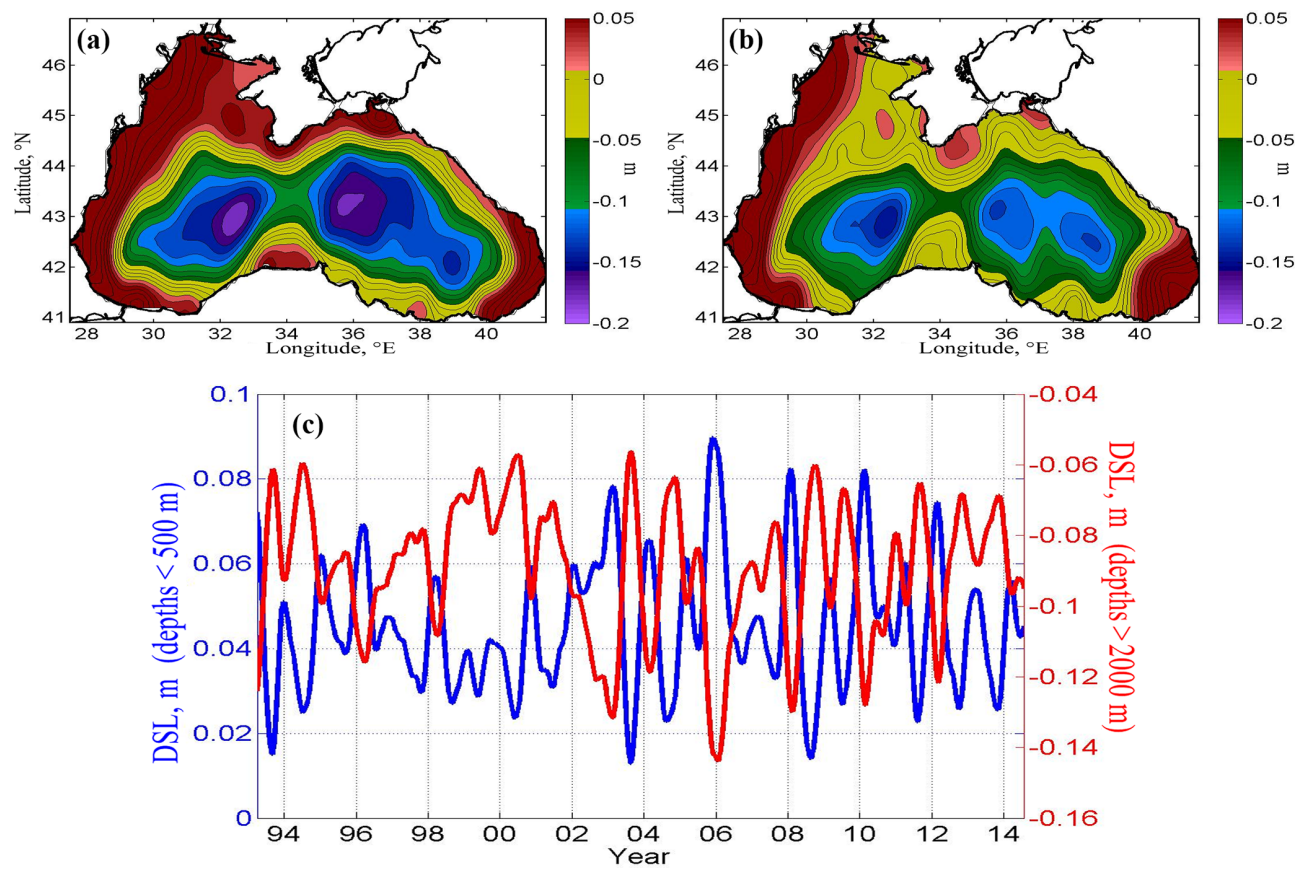

Figure 2. Average DSL distribution in (a) February, (b) July, and (c) DSL variability averaged over the central part (depths more than $2000 \mathrm{~m}$ ) and along the basin's periphery (depths less than $500 \mathrm{~m}$ ). Time series are smoothed by a 90-day moving average.

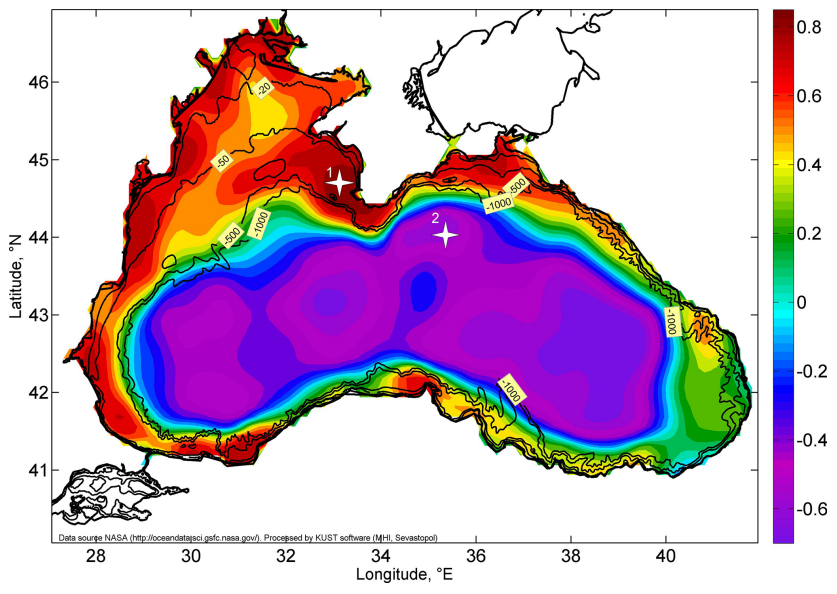

Figure 3. Correlation coefficients between the basin-averaged wind curl and DSL for the time series smoothed with a 365-day moving average (only interannual signals are retained). Solid black lines show isobaths $(20,50,500$, and $1000 \mathrm{~m})$.

Korotaev et al., 2001). In winter, the wind curl increases and intensifies the Ekman divergence, and as a result the DSL falls in the center of the basin and rises at the basin periphery (Fig. 2a). In summer the wind curl and divergence weakens and the water accumulated along the coast flows back into the basin's interior (Fig. 2b).

By the means of Ekman dynamics, fluctuations in the wind curl over the Black Sea also lead to changes in DSL on the longer timescales: strengthening of the wind curl increase the
DSL at the basin periphery and lower DSL at the basin center. As a result, the DSL in the basin's interior and periphery have an opposite variability with the correlation coefficient $(k=-0.91)$ (Fig. 2c) that was shown in previous studies (Stanev et al., 2000, 2001).

Displayed in Fig. 3 is correlation map between the wind curl averaged over the basin (i.e., the whole Black Sea) and DSL at each grid point for the time series, smoothed by a 365 -day moving average (only interannual variability is retained). The correlation coefficients are significantly positive $(>0.6)$ in shallow regions, with depths generally $<500 \mathrm{~m}$, and they are significantly negative in the deep interior of the basin $(<-0.6)$. The correlation map is consistent with the second EOF of the altimetry-derived sea level, which has been attributed to the effect of the wind curl (Grayek et al., 2009).

The correlation coefficients are high over the continental slope of the basin and the shelf areas, including the large northwestern shelf area. Over the continental slope, Ekman convergence leads to the downwelling motions and lowering of the pycnocline. A related decrease of density (steric effect) and the inflow of the water from the basin center both induce the sea level rise over the slope. In the shallow shelf areas, where stratification is weak, at least in winter months, the observed DSL variability is primarily caused by barotropic motions. The correlation is smaller in the southeast area of the basin, which is known as the area of the Batumi eddy (Oguz et al., 1993; Staneva et al., 2001; Korotaev et al., 2003; Kubryakov and Stanichny, 2015c). Here, the intense eddy dy- 


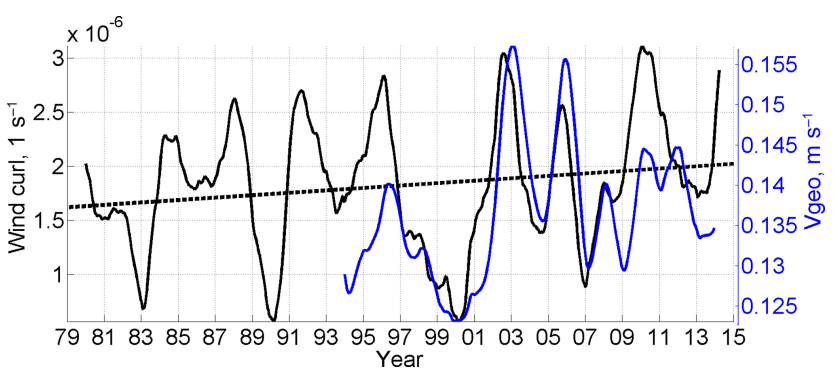

Figure 4. The interannual variability of the basin-averaged wind curl (black curve) in 1980-2014 and the basin-averaged speed of surface geostrophic currents (blue curve) smoothed with a 1-year moving average.

namics can alter the large-scale DSL changes caused by Ekman transport.

The interannual variability of the basin-averaged wind curl for the time period from 1979 to 2015 is rather complex, with several sharp minima in 1983, 1990, 2000, and 2007, and several less prominent maxima (Fig. 4). At the same time, it is noticeable that the wind curl is increasing over the entire period, including the period when the high-accuracy altimetry measurements are available (1993-2015). The value of the linear trend is $\sim(1 \pm 0.4) \times 10^{(-8)} \mathrm{s}^{-1}$ per year, which constitutes about $0.5 \%$ of the average value per year. The long-term trend of the wind curl induces a long-term intensification of the basin's cyclonic circulation that is indeed observed by satellite altimetry (Kubryakov and Stanichny, 2013; Kubryakov et al., 2016). The basin-averaged speed of surface geostrophic currents $U$ (Fig. 4 - blue curve) was increasing at an approximate rate of $0.05 \pm 0.003 \mathrm{~cm} \mathrm{~s}^{-1}$ per year, i.e., by $0.3 \%$ per year of the average value.

A positive trend of wind curl strengthens Ekman divergence, which lowers sea level in the center of the basin, and raises sea level along the coast. For example, Fig. 5 demonstrates the variability of DSL at two locations shown by crosses in Fig. 3: on the northwestern shelf $\left(33.2^{\circ} \mathrm{E} ; 44.7^{\circ} \mathrm{N}\right)$ and in the central basin $\left(35.4^{\circ} \mathrm{E}, 44.0^{\circ} \mathrm{N}\right)$. The time series of DSL (red curve) and the basin-averaged wind curl (blue curve) are strongly correlated for the first point on both the seasonal and interannual timescales, with the time lag of about 2 weeks (Kubryakov et al., 2016). The correlation coefficient for the lagged time series is 0.75 for 90 -day movingaverage smoothing, and it is 0.9 for the 365-day movingaverage smoothing. For the second location, characteristic for the basin's interior, the relationship between the sea level and wind curl is inverse (Fig. 5c, d). Here, the correlation is -0.84 for the time series smoothed with a 90-day moving average and -0.66 for the time series smoothed with a 365 -day moving average.

The average range of the interannual oscillations of DSL at the first point is about $5 \mathrm{~cm}$, in close agreement with the amplitudes of the DSL averaged along the basin's periphery (depths less than $500 \mathrm{~m}$ ) (Fig. 2c). The seasonal ranges of DSL reached $10 \mathrm{~cm}$ in 2003 and $8 \mathrm{~cm}$ in 2006 and 2008 . Based on tide gauge measurements, the characteristic range of seasonal oscillations of sea level at the Black Sea coastal stations is about $20 \mathrm{~cm}$ (Goryachkin and Ivanov, 2006). Thus, the seasonal variability of DSL explains up to $50 \%$ of the sea level variance and, therefore, makes an important contribution to the total sea level variability, in agreement with previous findings (Stanev et al., 2000; Grayek et al., 2009).

The linear trends of the DSL and wind curl (Fig. 5) are unidirectional (positive) in the basin's periphery and opposite in the basin's interior. The maximum increase of the cyclonic wind curl over the basin is observed in winter months (Fig. 6). As a result, the strongest intensification of the Black Sea circulation and rise of DSL at the basin periphery (depth less than $500 \mathrm{~m}$ ) occurs in winter (Kubryakov et al., 2016). The time required for the Black Sea circulation to adjust to changes in the wind curl is approximately 2 weeks (see Fig. 5a). That is why, on the graph of seasonal variability, we see that the maximum DSL trend (March) lags behind the maximum wind curl trend (February) by $\sim 1$ month (Fig. 6). The similar time lag (1-2 months) between DSL and wind curl variability was obtained in an earlier study of Stanev et al. (2000). Winter-early spring months are characterized by the maximum coastal vulnerability to the DSL rise, which reaches $\sim 1 \mathrm{~mm} \mathrm{yr}^{-1}$.

Based on the above considerations, the spatial distribution of the Black Sea trends presented in Fig. 1c can be explained by two factors: (a) the rise of the average BSSL by $3.15 \mathrm{~mm} \mathrm{yr}^{-1}$ due to the change of water mass and/or volume in the basin and (b) the increase of Ekman divergence in the center of the sea due to the strengthening of the cyclonic wind curl over the basin. The magnitude of the sea level rise related to the strengthening of the large-scale circulation and the Ekman divergence in the basin can be estimated from Fig.7a, which shows the DSL $=$ ADT - MSL trends map. It is equal to approximately $\left(+0.1 \ldots+0.5 \mathrm{~mm} \mathrm{yr}^{-1}\right)$ at the basin periphery and approximately $\left(-1 \ldots-1.5 \mathrm{~mm} \mathrm{yr}^{-1}\right)$ in the basin's interior. The value of the DSL trend constitutes about $15-50 \%$ of the basin-averaged sea level rise $\left(3.15 \mathrm{~mm} \mathrm{yr}^{-1}\right)$ and, therefore, plays an important role in sea level rise estimates.

\subsection{The impact of mesoscale variability on the sea level trends}

Several localized maxima are observed in the spatial distribution of the Black Sea DSL trends (Fig. 7a). The largest DSL trend (centered around $38.5^{\circ} \mathrm{E}, 42^{\circ} \mathrm{N}-$ Fig. $7 \mathrm{a}$ ) is located in the southeast corner of the Black Sea in the area of the quasi-stationary Batumi anticyclone (Oguz et al., 1993; Korotaev et al., 2003; Kubryakov and Stanichny, 2015c). The coincidence of the local maximum of sea level trend and the Batumi eddy position suggests that this maximum is related to the impact of eddy dynamics. 

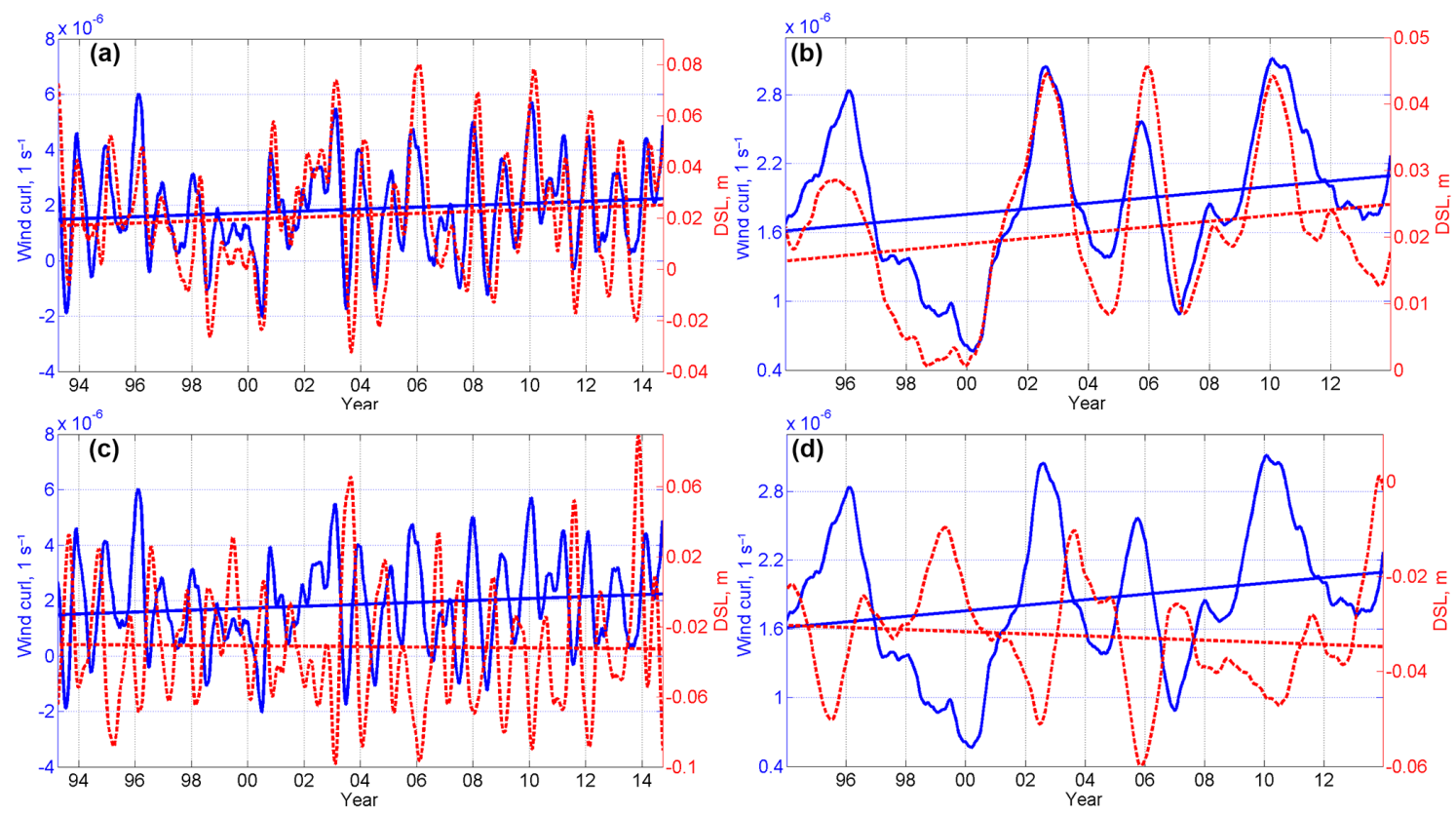

Figure 5. The time series and the linear trends of DSL (red curves) and the basin-averaged wind curl (blue curves): (a, b) at $33.2^{\circ} \mathrm{E}, 44.8^{\circ} \mathrm{N}$ (the basin's periphery) and (c, d) at $35.4^{\circ} \mathrm{E}, 44.0^{\circ} \mathrm{N}$ (center of the basin); the time series are smoothed (a, c) with a 90-day moving average time series and $(\mathbf{b}, \mathbf{d})$ with a 365 -day moving average.

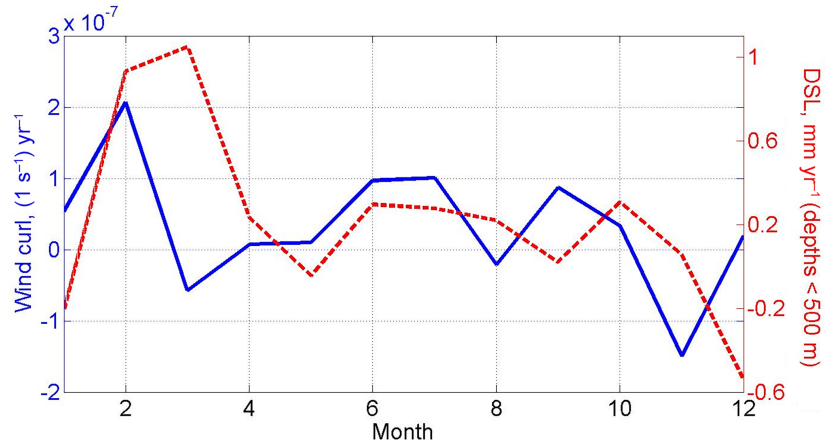

Figure 6. Monthly distribution of the wind curl (blue curve, $1 \mathrm{~s}$ per year) and DSL trends (red curve, $\mathrm{mm} \mathrm{yr}^{-1}$ ) at the basin periphery.

Displayed in Fig. $7 b-d$ are the linear trends of (b) frequency, (c) orbital velocity, and (d) radius of the Black Sea eddies, estimated using the "winding angle" method. Although the estimated trends are rather patchy due to complex eddy dynamics, it is still possible to identify some significant trends of the radius and orbital velocity of anticyclones that coincide with the areas of stronger sea level rise. The spatial pattern of the largest eddy frequency trend is located in the southeastern part, and it coincides with the position of rising DSL (Fig. 7b). Positive trends of eddy radius and orbital velocity are observed on the western and eastern sides of this pattern. This suggests that the Batumi anticyclone was expanding in the zonal direction, and began to occupy a larger area in the southeast part of the basin. In the intensifying an- ticyclonic eddies, sea level rises, as the eddies induce convergent motions and accumulation of the surface waters in their core (see, e.g., Siegel et al., 1999). The rise and intensification of the Batumi eddy leads to the consequent rise of the dynamic sea level in the areas in which the eddy expands.

The interannual variability of the anticyclonic eddy properties at the point $38.5^{\circ} \mathrm{E}, 42^{\circ} \mathrm{N}$, which corresponded to the largest DSL trend in the southeast of the Black Sea, is shown in Fig. 8. Both the frequency of eddies and their intensity were increasing with time. The frequency of eddies doubled from $4 \%$ in the early 1990 s to $\sim 8 \%$ in 2010s (Fig. 8 a). The maximum orbital velocity of anticyclones at this point almost tripled from $0.14 \mathrm{~m} \mathrm{~s}^{-1}$ in 1995 to $\sim 0.4 \mathrm{~m} \mathrm{~s}^{-1}$ in 2014 (Fig. 7b). Observed intensification of anticyclonic motions cause the largest sea level rise in the southeast corner of the Black Sea. Several other local maxima in the trends of the frequency of anticyclones coincide with the positions of increased sea level trends. For example, a local DSL maximum near $31.5^{\circ} \mathrm{E}, 44^{\circ} \mathrm{N}$ (Fig. $7 \mathrm{a}$ ) is close to a local maximum in the trend of the frequency and velocity of anticyclones. The variability of the eddy dynamics is one of the reasons for the observed patchiness of the BSSL trends.

\subsection{Reconstruction of DSL variability using wind data}

Before the advent of high-resolution altimetry in 1992, tide gauges were used to estimate the basin-averaged sea level rise. As demonstrated above, coastal sea level measurements include DSL, but the latter does not reflect changes in the Black Sea water volume (Stanev et al., 2001). Therefore, 

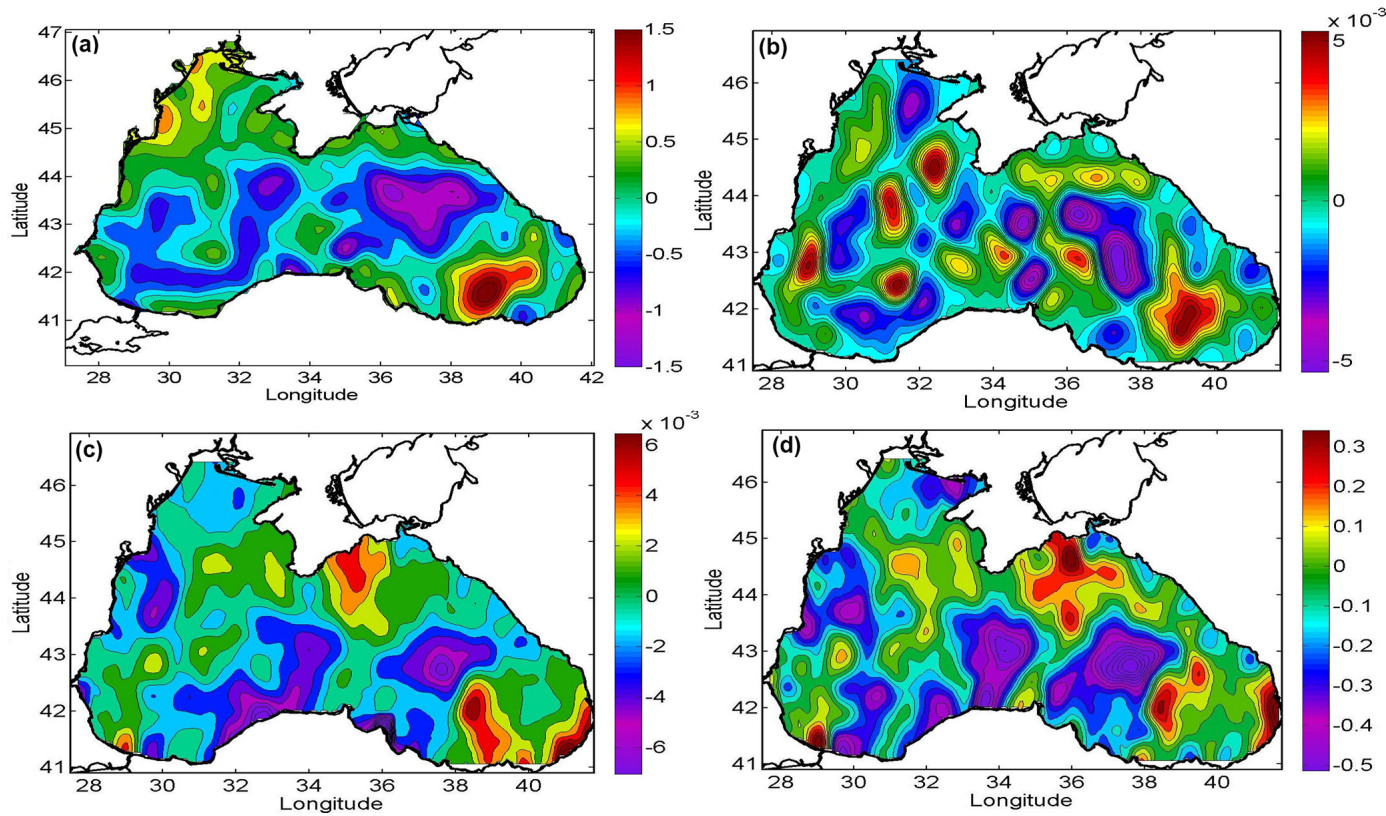

Figure 7. Spatial distribution of (a) DSL trends $\left(\mathrm{mm} \mathrm{yr}^{-1}\right)$. (b) Trends in the frequency of anticyclones in $1993-2014\left(1 \mathrm{yr}^{-1}\right)$. (c) Trends in the maximum orbital velocity of anticyclones in 1993-2014 $\left(\mathrm{m} \mathrm{s}^{-1} \mathrm{yr}^{-1}\right)$. (d) Trends in the radius of anticyclones in 1993-2014 (km yr $\left.{ }^{-1}\right)$.
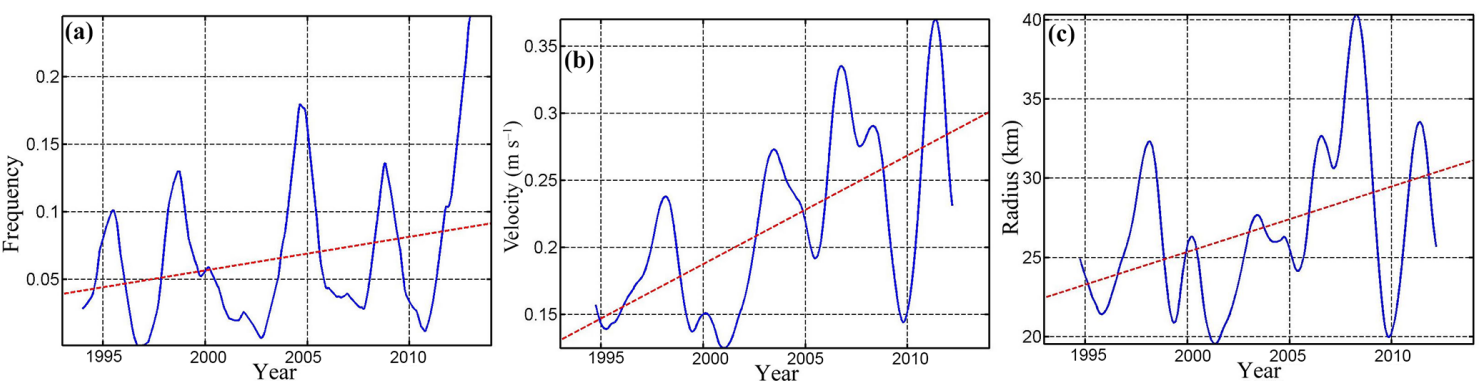

Figure 8. (a) Frequency, (b) maximum orbital velocity, and (c) radius of anticyclones at $38.5^{\circ} \mathrm{E}, 42^{\circ} \mathrm{N}$, derived from altimetry data.

the tide gauge trends should be corrected for DSL in order to obtain better estimates of the basin-averaged sea level trends. To determine the DSL correction, we computed the linear regression coefficients $(k)$ between the basin-averaged wind curl $(W)$ and DSL at each grid point: DSL $=k \times W+\varepsilon$ (Fig. 9), where $\varepsilon$ is the error term.

Then we reconstructed DSL using the regression coefficients and the wind curl. Standard deviations of the error term on the interannual timescale (the time series are smoothed with a 1-year moving average) are rather small along the coast and over the northwestern shelf (Fig. 9b), generally less than $1 \mathrm{~cm}$. In the interior of the basin and, in particular, in the area of the Batumi anticyclone, the errors are larger (2$3 \mathrm{~cm}$ ), which is apparently due to the impact of mesoscale dynamics. Displayed in Fig. 10 are the altimetry-derived and reconstructed DSL at a location near the south Crimean coast $\left(33.2^{\circ} \mathrm{E}, 44.7^{\circ} \mathrm{N}\right)$. The correlation coefficients between the time series are 0.85 and 0.88 for the time series smoothed by 90-day (Fig. 10a) and 365-day (Fig. 10b) moving averages, respectively. Our analysis suggests that a simple linear regression is capable of capturing both the seasonal and interannual variability of DSL from the wind data alone.

Since the ERA-Interim winds are available for a longer period (since 1979) than altimetry data, the obtained regression coefficients can be used to reconstruct the DSL variability in the past and correct the estimates of the BSSL rise based on tide gauges. For example, the DSL trend over the 1979-1992 period at a point near the south Crimean coast $\left(33.2^{\circ} \mathrm{E}, 44.7^{\circ} \mathrm{N}\right)$ is $0.3 \mathrm{~mm} \mathrm{yr}^{-1}$. Then, this value should be subtracted from nearby tide gauge records that are used to compute the basin-averaged sea level change in the Black Sea. It should be noted that this method accounts only for changes in the large-scale circulation, but does not account for trends in mesoscale dynamics. Nevertheless, based on our analysis it is reasonable to assume that the mesoscale dynamics mostly affect the basin's interior, while the coastal 

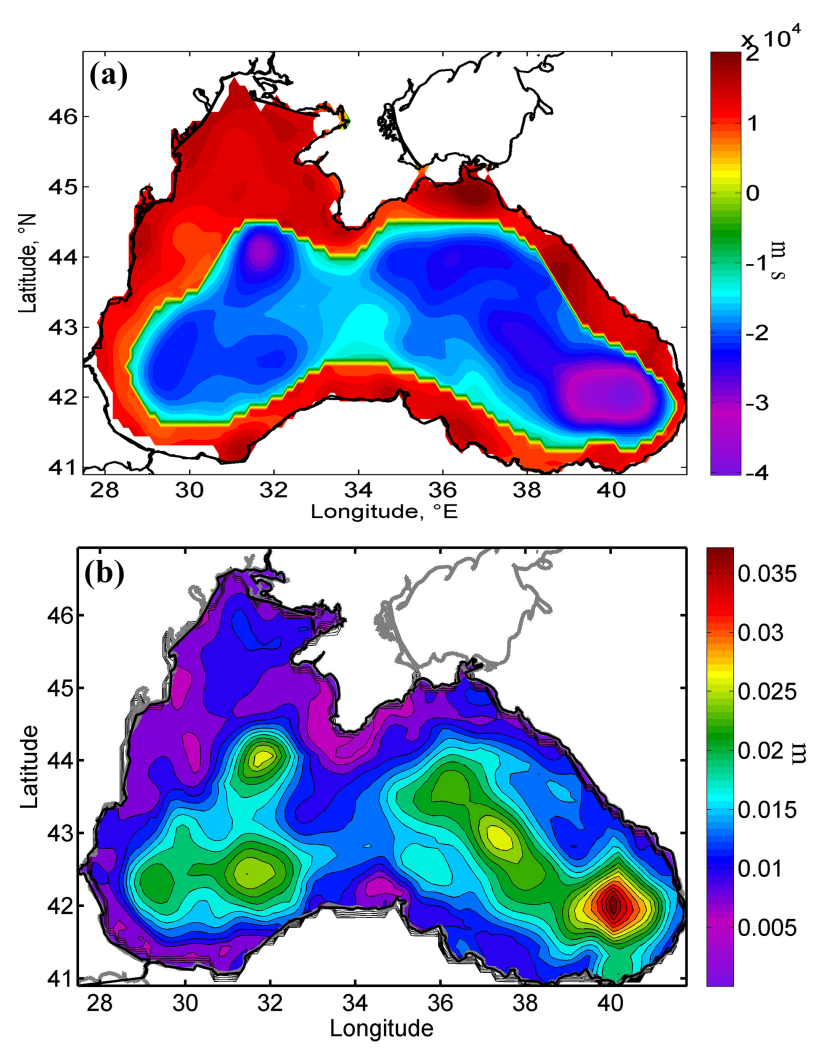

Figure 9. (a) Linear regression coefficients $(k)$ between the basinaveraged wind curl and DSL (DSL $=k \times W+\varepsilon$ ). (b) Standard deviations of the error term (the difference between the altimetry-derived and reconstructed DSL); time series are smoothed with a 1-year moving average.
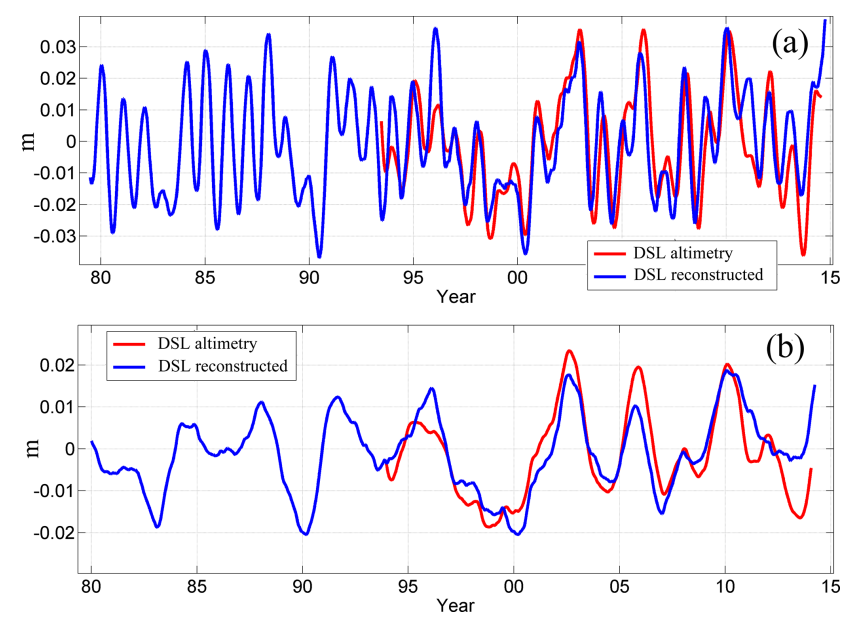

Figure 10. The time series of the altimetry-derived DSL (red curve) and DSL at $33.2^{\circ} \mathrm{E}, 44.7^{\circ} \mathrm{N}$, reconstructed from the wind curl (blue curve): the time series are smoothed (a) with a 90-day moving average and (b) with a 365-day moving average. sea level variability is mostly driven by Ekman dynamics (Fig. 9b).

\section{Conclusions}

The climatic changes of the large-scale and mesoscale dynamics in the Black Sea significantly impact sea level trends in different parts of the basin. While the basin-averaged sea level has been rising by $3.15 \mathrm{~mm} \mathrm{yr}^{-1}$, sea level trends vary from $1.5 \mathrm{~mm} \mathrm{yr}^{-1}$ in the interior to $3.5-3.8 \mathrm{~mm} \mathrm{yr}^{-1}$ in coastal areas and to $5 \mathrm{~mm} \mathrm{yr}^{-1}$ in the southeastern part of the sea. We have shown that the observed long-term intensification of the cyclonic wind curl strengthened divergence in the center of the basin, which caused a rise of the sea level along the Black Sea coast and over the northwestern shelf, and a lowering of sea level in the interior of the basin. In addition, we show that changes in the distribution and intensity of mesoscale eddies led to the local extremes in sea level trends. In particular, an extension of the Batumi anticyclone resulted in an excess sea level rise in the southeastern part of the basin by $\sim 1.2 \mathrm{~mm} \mathrm{yr}^{-1}$.

The DSL associated with the redistribution of water masses within the Black Sea varies considerably on seasonal and interannual timescales. For example, the maximum trend of the wind curl causing an associated DSL rise of $\sim 1 \mathrm{~mm} \mathrm{yr}^{-1}$ is observed in winter months. The amplitudes of the DSL variability can reach $10 \mathrm{~cm}$ in different years, and they contribute up to $50 \%$ of the total annual sea level signal, in agreement with Stanev et al. (2000). We have demonstrated that the DSL variability can be reconstructed using the linear regression between the wind curl and DSL. The reconstructed DSL can be used to correct historical (prior to altimetry era) estimates of the basin-averaged sea level rise, based on coastal tide gauge measurements.

Data availability. Satellite altimetry data is produced by Ssalto/Duacs and distributed by Aviso, with support from CNES (www.aviso.oceanobs.com). ERA-Interim reanalysis data is produced by ECMWF and is available from (http://apps.ecmwf.int).

Competing interests. The authors declare that they have no conflict of interest.

Acknowledgements. Kubryakov A. A. was supported by RFBR, according to the research project no. 16-35-60036 mol_a_dk. Stanichny S. V. was supported by RSF, the research grant 15-1720020. D. L. Volkov was supported by the NASA Ocean Surface Topography Science Team program (grant NNX13AO73G) and by the base funds of NOAA Atlantic Oceanographic and Meteorological Laboratory. Satellite and meteorological data collection was supported by the Federal Agency for Scientific Organizations (FASO Russia) project no. 0827-2015-0001. 
Edited by: J. M. Huthnance

Reviewed by: two anonymous referees

\section{References}

Aksoy, A.: Investigation of sea level trends and the effect of the north atlantic oscillation (NAO) on the black sea and the eastern mediterranean sea, Theor. Appl. Climatol., https://doi.org/10.1007/s00704-016-1759-0, online first, 2016.

Allenbach, K., Garonna, I., Herold, C., Monioudi, I., Giuliani, G., Lehmann, A., and Velegrakis, A.: Black Sea beaches vulnerability to sea level rise, Environ. Sci. Policy, 46, 95-109, https://doi.org/10.1016/j.envsci.2014.07.014, 2015.

Alpar, B.: Vulnerability of Turkish coasts to accelerated sea-level rise, Geomorphology, 107, 58-63, https://doi.org/10.1016/j.geomorph.2007.05.021, 2009.

Avsar, N. B., Kutoglu, S. H., Jin, S., and Erol, B.: INVESTIGATON OF SEA LEVEL CHANGE ALONG THE BLACK SEA COAST FROM TIDE GAUGE AND SATELLITE ALTIMETRY, Int. Arch. Photogramm. Remote Sens. Spatial Inf. Sci., XL1/W5, 67-71, https://doi.org/10.5194/isprsarchives-XL-1-W567-2015, 2015.

Avsar, N. B., Jin, S., Kutoglu, H., and Gurbuz, G.: Sea level change along the Black Sea coast from satellite altimetry, tide gauge and GPS observations, Geodesy and Geodynamics, 7, 50-55, https://doi.org/10.1016/j.geog.2016.03.005, 2016.

Blatov, A. S., Bulgakov, N. P., Ivanov, V. A., Kosarev, A. N., and Tujilkin, V. S.: Variability of hydrophysical fields in the Black Sea, Gidrometeoizdat, Leningrad, 1984 (in Russian).

Boguslavsky, S. G., Kubryakov, A. I., and Ivashchenko, I. K.: Variations of the Black Sea level, Phys. Oceanogr., 9, 199-208, https://doi.org/10.1007/bf02523230, 1998.

Carrère, L. and Lyard, F.: Modeling the barotropic response of the global ocean to atmospheric wind and pressure forcing - comparisons with observations, Geophys. Res. Lett., 30, 8-1-8.4, https://doi.org/10.1029/2002gl016473, 2003.

Cazenave, A.: Sea level variations in the Mediterranean Sea and Black Sea from satellite altimetry and tide gauges, Global Planet. Change, 34, 59-86, https://doi.org/10.1016/s09218181(02)00106-6, 2002.

Cazenave, A. and Llovel, W.: Contemporary Sea Level Rise, Annual Review of Marine Science, 2, 145-173, https://doi.org/10.1146/annurev-marine-120308-081105, 2010.

Chaigneau, A., Gizolme, A., and Grados, C.: Mesoscale eddies off Peru in altimeter records: Identification algorithms and eddy spatio-temporal patterns, Prog. Oceanogr., 79, 106-119, https://doi.org/10.1016/j.pocean.2008.10.013, 2008.

Church, J. A., White, N. J., Coleman, R., Lambeck, K., and Mitrovica, J. X.: Estimates of the Regional Distribution of Sea Level Rise over the 1950-2000 Period, J. Climate, 17, 2609-2625, https://doi.org/10.1175/15200442(2004)017<2609:eotrdo>2.0.co;2, 2004.

Church, J. A., Clark, P. U., Cazenave, A., Gregory, J. M., Jevrejeva, S.; Levermann, A., Merrifield, M. A., Milne, G. A., Nerem, R. S., Nunn, P. D., Payne, A. J., Pfeffer, W.,T., Stammer, D., and Unnikrishnan, A. S.: Climate Change 2013: The Physical Science Basis. Contribution of Working Group I to the Fifth Assessment
Report of the Intergovernmental Panel on Climate Change, edited by: Stocker, T. F., Qin, D., Plattner, G.-K., Tignor, M., Allen, S. K., Boschung, J., Nauels, A., Xia, Y., Bex, V., and Midgley, P. M., Cambridge, UK, 1137-1216, 2013.

Dee, D. P., Uppala, S. M., Simmons, A. J., Berrisford, P., Poli, P., Kobayashi, S., Andrae, U., Balmaseda, M. A., Balsamo, G., Bauer, P., Bechtold, P., Beljaars, A. C. M., van de Berg, L., Bidlot, J., Bormann, N., Delsol, C., Dragani, R., Fuentes, M., Geer, A. J., Haimberger, L., Healy, S. B., Hersbach, H., Hólm, E. V., Isaksen, L., Kållberg, P., Köhler, M., Matricardi, M., McNally, A. P., Monge-Sanz, B. M., Morcrette, J.-J., Park, B.-K., Peubey, C., de Rosnay, P., Tavolato, C., Thépaut, J.-N., and Vitart, F.: The ERA-Interim reanalysis: configuration and performance of the data assimilation system, Q. J. Roy. Meteorol. Soc., 137, 553597, https://doi.org/10.1002/qj.828, 2011.

Demirkesen, A., Evrendilek, F., and Berberoglu, S.: Quantifying coastal inundation vulnerability of Turkey to sea-level rise, Environ. Monit. Assess., 138, 101-106, https://doi.org/10.1007/s10661-007-9746-7, 2007.

Ducet, N., Le Traon, P., and Gauzelin, P.: Response of the Black Sea mean level to atmospheric pressure and wind forcing, J. Marine Syst., 22, 311-327, https://doi.org/10.1016/s09247963(99)00072-x, 1999.

Garmashov, A. V., Kubryakov, A. A., Shokurov, M. V., Stanichny, S. V., Toloknov, Y. N., and Korovushkin, A. I.: Comparing satellite and meteorological data on wind velocity over the Black Sea, Izvestiya, Atmos. Ocean. Phys., 52, 309-316, https://doi.org/10.1134/s000143381603004x, 2016.

Ginzburg, A. I., Kostianoy, A. G., Sheremet, N. A., and Lebedev, S. A.: Satellite altimetry applications in the Black Sea, in: Coastal Altimetry, Springer, Berlin, Heidelberg, 367-387, 2011.

Goryachkin, Y. N. and Ivanov, V. A.: The Black Sea Level: Past, Present and Future, Sevastopol, MHI, 2006 (in Russian).

Goryachkin, Y. N., Ivanov, V. A., Lemeshko, E. M., and Lipchenko, M. M.: Application of the Altimetry Data to the Analysis of Water Balance of the Black Sea, Phys. Oceanogr., 13, 355-360, https://doi.org/10.1023/b:poce.0000013232.31952.a9, 2003.

Grayek, S., Stanev, E. V., and Kandilarov, R.: On the response of Black Sea level to external forcing: altimeter data and numerical modelling, Ocean Dynam., 60, 123-140, https://doi.org/10.1007/s10236-009-0249-7, 2009.

Ilyin, Y. P., Repetin, L. N., Belokopytov, V. N., Goryachkin, Y. N, Dyakov, N. N., Kubryakov, A. A., and Stanichny, S. V.: Meteorological conditions of the seas of Ukraine, Black Sea, vol. 2, ECOSY-Gidrofizika, Sevastopol, 2012 (in Russian).

Jevrejeva, S., Grinsted, A., Moore, J. C., and Holgate, S.: Nonlinear trends and multiyear cycles in sea level records, J. Geophys. Res., 111, C09012, https://doi.org/10.1029/2005jc003229, 2006.

Korotaev, G. K., Saenko, O. A., Koblinsky, C. J., Demishev, S. G., and Knysh, V. V.: An accuracy, methodology, and some results of the assimilation of the TOPEX/Poseidon altimetry data into the model of the Black Sea general circulation, Earth Res. Space, 3, 3-17, 1998.

Korotaev, G. K., Saenko, O. A., and Koblinsky, C. J.: Satellite altimetry observations of the Black Sea level, J. Geophys. Res.Oceans, 106, 917-933, https://doi.org/10.1029/2000jc900120, 2001.

Korotaev, G., Oguz, T., Nikiforov, A., and Koblinsky, C.: Seasonal, interannual, and mesoscale variability of the Black Sea upper 
layer circulation derived from altimeter data, J. Geophys. Res., 108, 3122, https://doi.org/10.1029/2002JC001508, 2003.

Kos'Yan, R., Kuklev, S., Khanukaev, B., and Kochergin, A.: Problems of the coasts erosion in the North-Eastern Black Sea Region, Journal of Coastal Conservation, 16, 243-250, https://doi.org/10.1007/s11852-010-0115-2, 2010.

Kubryakova, E. and Korotaev, G.: Mechanism of horizontal massand salt-exchange between the waters of continental slope and central part of the Black Sea, Izvestiya, Atmos. Ocean. Phys., 53, 102-110, https://doi.org/10.1134/s0001433817010078, 2017.

Kubryakov, A. A. and Stanichny, S. V.: Mean Dynamic Topography of the Black Sea, computed from altimetry, drifter measurements and hydrology data, Ocean Sci., 7, 745-753, https://doi.org/10.5194/os-7-745-2011, 2011.

Kubryakov, A. and Stanichny, S.: Estimating the quality of the retrieval of the surface geostrophic circulation of the Black Sea by satellite altimetry data based on validation with drifting buoy measurements, Izvestiya, Atmos. Ocean. Phys., 49, 930-938, https://doi.org/10.1134/s0001433813090089, 2013.

Kubryakov, A. A. and Stanichnyi, S. V.: The Black Sea level trends from tide gages and satellite altimetry, Russ. Meteorol. Hydrol., 38, 329-333, https://doi.org/10.3103/s1068373913050051, 2013.

Kubryakov, A. A. and Stanichny, S. V.: Mesoscale eddies in the Black Sea from satellite altimetry data, Oceanology, 55, 56-67, https://doi.org/10.1134/s0001437015010105, 2015a.

Kubryakov, A. and Stanichny, S.: Seasonal and interannual variability of the Black Sea eddies and its dependence on characteristics of the large-scale circulation, Deep-Sea Res. Pt. I, 97, 80-91, https://doi.org/10.1016/j.dsr.2014.12.002, 2015b.

Kubryakov, A. and Stanichny, S.: Dynamics of Batumi Anticyclone from the Satellite Measurements, Morskoy gidrofizicheskiy zhurnal, 2, 59-68, https://doi.org/10.22449/0233-75842015-2-67-78, 2015c.

Kubryakov, A., Stanichny, S., Zatsepin, A., and Kremenetskiy, V.: Long-term variations of the Black Sea dynamics and their impact on the marine ecosystem, J. Marine Syst., 163, 80-94, https://doi.org/10.1016/j.jmarsys.2016.06.006, 2016.

Lynch, D. and Gray, W.: A wave equation model for finite element tidal computations, Comput. Fluids, 7, 207-228, https://doi.org/10.1016/0045-7930(79)90037-9, 1979.

Marcos, M., Pascual, A., and Pujol, I.: Improved satellite altimeter mapped sea level anomalies in the Mediterranean Sea: A comparison with tide gauges, Adv. Space Res., 56, 596-604, https://doi.org/10.1016/j.asr.2015.04.027, 2015.

Oguz, T., Latun, V., Latif, M., Vladimirov, V., Sur, H., Markov, A., Özsoy, E., Kotovshchikov, B., Eremeev, V., and Ünlüata, Ü.: Circulation in the surface and intermediate layers of the Black Sea, Deep-Sea Res. Pt. I, 40, 1597-1612, https://doi.org/10.1016/0967-0637(93)90018-x, 1993.

Peneva, E., Stanev, E., Belokopytov, V., and Le Traon, P.: Water transport in the Bosphorus Straits estimated from hydrometeorological and altimeter data: seasonal to decadal variability, J. Marine Syst., 31, 21-33, https://doi.org/10.1016/s09247963(01)00044-6, 2001.
Reva, Y. A.: Interannual oscillations of the Black Sea level, Oceanology, 37, 193-200, 1997.

Siegel, D., McGillicuddy, D., and Fields, E.: Mesoscale eddies, satellite altimetry, and new production in the Sargasso Sea, J. Geophys. Res.-Oceans, 104, 13359-13379, https://doi.org/10.1029/1999jc900051, 1999.

Simonov, A. I. and Altman, E. N.: Hydrometeorology and Hydrochemistry of the USSR Seas, The Black Sea, 4, 430 pp., 1991.

Stanev, E.: On the mechanisms of the Black Sea circulation, Earth-Sci. Rev., 28, 285-319, https://doi.org/10.1016/00128252(90)90052-w, 1990.

Stanev, E. and Peneva, E.: Regional sea level response to global climatic change: Black Sea examples, Global Planet. Change, 32, 33-47, https://doi.org/10.1016/s0921-8181(01)00148-5, 2001.

Stanev, E., Le Traon, P., and Peneva, E.: Sea level variations and their dependency on meteorological and hydrological forcing: Analysis of altimeter and surface data for the Black Sea, J. Geophys. Res.-Oceans, 105, 17203-17216, https://doi.org/10.1029/1999jc900318, 2000.

Stanev, E., Staneva, J., Bullister, J., and Murray, J.: Ventilation of the Black Sea pycnocline. Parameterization of convection, numerical simulations and validations against observed chlorofluorocarbon data, Deep-Sea Res. Pt I, 51, 2137-2169, https://doi.org/10.1016/j.dsr.2004.07.018, 2004.

Staneva, J., Dietrich, D., Stanev, E., and Bowman, M.: Rim current and coastal eddy mechanisms in an eddy-resolving Black Sea general circulation model, J. Marine Syst., 31, 137-157, https://doi.org/10.1016/s0924-7963(01)00050-1, 2001.

Tsimplis, M., Josey, S., Rixen, M., and Stanev, E.: On the forcing of sea level in the Black Sea, J. Geophys. Res.-Oceans, 109, 1-13, https://doi.org/10.1029/2003jc002185, 2004.

Tsimplis, M. N. and Spencer, N. E.: Collection and analysis of monthly mean sea level data in the Mediterranean and the Black Sea, J. Coastal Res., 13, 534-544, 1997.

Vigo, I., Garcia, D., and Chao, B.: Change of sea level trend in the Mediterranean and Black seas, J. Mar. Res., 63, 1085-1100, https://doi.org/10.1357/002224005775247607, 2005.

Volkov, D. and Landerer, F.: Internal and external forcing of sea level variability in the Black Sea, Clim. Dynam., 45, 2633-2646, https://doi.org/10.1007/s00382-015-2498-0, 2015.

Volkov, D., Larnicol, G., and Dorandeu, J.: Improving the quality of satellite altimetry data over continental shelves, J. Geophys. Res., 112, 1-20, https://doi.org/10.1029/2006jc003765, 2007.

Volkov, D., Johns, W., and Belonenko, T.: Dynamic response of the Black Sea elevation to intraseasonal fluctuations of the Mediterranean sea level, Geophys. Res. Lett., 43, 283-290, https://doi.org/10.1002/2015gl066876, 2016.

Yildiz, H., Andersen, O. B., Kilicoglu, A., Simav, M., and Lenk, O.: Sea level variations in the Black Sea for 1993-2007 period from GRACE, altimetry and tide gauge data, Geoph. Res. Abs., Vol. 10, EGU2008-A-08684, 2008.

Zatsepin, A. G., Kremenetskiy, V. V., Poyarkov, S. G., Ratner, Y. B., and Stanichny, S. V: Influence of wind field on water circulation in the Black Sea, in: Complex Investigation of the Northeastern Black Sea, Nauka, Moscow, 91-105, 2002. 